\title{
Work process of an oral health team according to the dentists
}

\author{
Rotina de trabalho da equipe de saúde bucal sob a ótica do cirurgião dentista
}

Flávia Martão FLÓRIO'

Mariana Boanova LOURENÇO'

Arlete Maria Gomes OLIVEIRA ${ }^{1}$

Luciane ZANIN ${ }^{1}$

\section{ABSTRACT}

\section{Objective}

The aim of this study, conducted with the participation of the dentists of public service of Campinas, Dental Hygienist Technicians (TSBs) and Oral Health Assistants (ASBS), was to investigate the adequacy of the work process relative to the legal duties and professional limits.

\section{Methods}

All the 180 dentists linked to the public service in 2014 were invited to take part in the study. Structured and self-administered questionnaires were sent to the these professional and they focused on vocational training and the allocation of functions in routine health care based on the provision of Law 11.889/2008.

\section{Results}

Considering the respondents, the post-graduation period was $22.1 \pm 7.4$ years and they had a mean number $16.2 \pm 8.9$ years of public service. The majority of dentists worked with assistants (82.8\%) during the period of study. Regarding the functions delegated to assistants, of the 36 functions identified, it was noted that 14 (38.9\%) of the functions delegated diverged from their legal attributes, for most respondents; of these $35.7 \%$ (5) denoted extrapolation of ASBs functions, $28.6 \%$ (4) extrapolation of TSBs functions and 35.7\% (5) underutilization of assistants, in particular TSBs.

\section{Conclusion}

The authors concluded that most actions were being delegated in a manner consistent with the legal provisions, however, there were still situations of extrapolation of assistant's functions and underutilization of TSBS.

Indexing terms: Dental auxiliaries. Dental staff. Oral health. Professional competence.

\section{RESUMO}

\section{Objetivo}

Investigar junto aos dentistas da rede pública de Campinas a adequação da rotina de trabalho em equipe com as atribuições legais e os limites de atuação profissional, dos Técnicos em Saúde Bucal (TSBs) e Auxiliares em Saúde Bucal (ASBs).

\section{Métodos}

Todos os 180 dentistas da atenção básica do serviço público receberam questionários estruturados e auto administrados, com foco na formação profissional e na atribuição de ações na rotina da atenção em saúde, com base na disposição da lei 11.889/2008.

\section{Resultados}

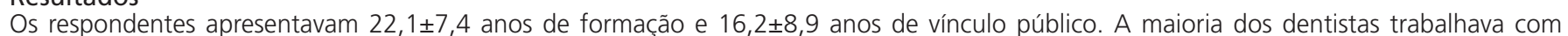
auxiliar (82,8\%). Quanto às ações, das 36 funções apontadas, 14 (38,9\%) apresentaram delegação divergente às atribuições legais para a maioria dos respondentes, dentre as quais, 35,7\% (5) denotavam extrapolação de funções de ASB, 28,6\% (4) extrapolação de função de TSB e $35,7 \%$ (5) subutilização dos auxiliares, em especial do TSB.

\section{Conclusão}

Conclui-se que a maioria das ações está sendo delegada de maneira condizente à disposição legal, havendo, no entanto, situações de extrapolação de funções dos auxiliares e de subutilização dos TSB.

Termos de indexação: Auxiliares de Odontologia. Recursos humanos em Odontologia. Saúde bucal. Competência profissional.

\section{INTRODUCTION}

The professional work of dental assistants was legalized by the CFO Resolution No. 185/1993 and changed by Resolution No. $209 / 1997^{1}$. Its profile of competences was published in $2004^{2}$ and extended by the National Oral Health Policy ${ }^{3}$. But it was only in 2008 that Federal Law No.11889 was sanctioned, which regulated to exercise of assistant professions: Oral Health Technician (TSB) and Oral Health Assistant (ASB) ${ }^{4}$.

\footnotetext{
${ }^{1}$ Faculdade São Leopoldo Mandic, Curso de Odontologia, Programa de Pós-Graduação em Saúde Coletiva. Rua José Rocha Junqueira, 13, Swift, 13045-

755, Campinas, SP, Brasil. Correspondência para / Correspondence to: FM FLÓRIO. E-mail: <flaviaflorio@yahoo.com>.
} 
One of the factors that triggered the legalization of professional assistants was the role played by SUS, which assumed the priority of human resources development for professionalization of workers in the primary care network, in the sense of reorienting and qualifying professional practice. Furthermore, the Ministry of Health Administrative Ruling No.267 of March 5, 2001, which instituted the rules and guidelines for the inclusion of oral health in the family health strategy, structured dental care as a product of the oral health team's work.

From the time this measure was introduced, a significant increase in the work market was noted for components of the oral health, and a perceptible intensification of the education and hiring of auxiliary personnel for the public sector ${ }^{5}$. But a deeper look into the distribution of these opportunities showed, that in April 2015, with 35673 Oral Heal Teams (ESBs) implemented in the country, the jobs for CDs, TSBs and ASBs were distributed as follows: $45.4 \%, 9.1 \%$ and $45.4 \%$, respectively ${ }^{6}$. In Campinas, this proportion has improved significantly with the passage of time, so that from 2014 through to April, 2016 there was a better distribution of vacancies among the components of the ESB, as there was an increase from $7 \%$ to $21 \%$ in jobs for $\mathrm{TSBs}^{6}$.

The use of auxiliary labor in the dental clinical has been shown to be a necessity for optimizing productivity; increasing the technical quality; as well as adding comfort and safety in caring for patients; reducing physical wear, stress and fatigue of Dental Surgeons - CD; minimizing the operating costs and opening the population's access to oral health care ca $^{7-9}$

Nevertheless, for CDs to achieve this maximum productivity, it is necessary for them to use auxiliary personnel, and know how to delegate functions ${ }^{9-10}$. A large portion of dentists have not yet learned how to work as a team, and maintain the monopoly of activities and functions that could and must be delegated ${ }^{8,11}$. Esposti et al. ${ }^{5}$ verified that although dentists understood that the relationship of partnership and cooperation with the TSBs was fundamental, negative ideas persisted and were related to the fear of losing the work market, and the legal responsibility related to their activities, foreseen in the regulation of exercising the profession. Along this line, in the law there is nothing attributed to CDs that allows them to reduce/curtail the professional skills of assistants ${ }^{12-13}$.

The perception of assistants with regard to the work process and to the adequacy of their functions as a result of the new legislation has been investigated in both the public ${ }^{9,14}$ and private sectors ${ }^{8,15}$. However, the dentists view about this question is till incipient and focused on the role of the dentist-professor in the education of the technicians ${ }^{5}$.

Since the dentists in the public service are included in the context of multiprofessional team work, and in theory, act within the limits and skills applied to the other professions, the present study with participation of the dentists of the public network of Campinas, sought to investigate the adequacy of the process of working in a team with the legal attributions and limits of professional activity of the oral health technicians and assistants, based on the legislation in force.

\section{METHODS}

\section{Ethical aspects of the research}

This type of observational, cross-sectional and quantitative study was conducted in accordance with the precepts determined by Resolution No.466 of 2012 . The present study was approved by the Research Ethics Committee of the School of Dentistry and Post-Graduation Center, São Leopoldo Mandic, under Report Number 694.049 of June 23, 2014.

\section{Study population}

The municipality of Campinas (São Paulo) is divided into five districts, and at the beginning of the study in 2014, had sixty-two (62) health centers (CS)with multiprofessional teams. At that time, dental care was available at all the health centers, with the exception of CS Lisa and CS Campina Grande, in the Northwestern region. According to data from the Primary Care Department of the Ministry of Health, the municipality of Campinas had coverage of $33 \%$ of its population of $1,098,630$ inhabitants, by 37 oral health teams - modality I, and 7 oral health teams - modality II. In the other centers, dental care was being organized according to the logic of traditional assistance. Al of the 60 Health Centers with dentists working, were contacted, corresponding to a universe of 180 dentists.

\section{Research instruments and application strategy}

Data was collected by means of structured, self-administered, pre-tested questionnaires. They were elaborated, based on Federal Law No. 11,889/20084, in Report No. 460/1975 of the Federal Council of Education 
(CFE) ${ }^{16}$, in Resolution No. 63/2005 of the Federal Council of Dentistry (CFO) ${ }^{17}$ and on critical analysis of the legislation, made by Frazão and $\mathrm{Narvai}^{13}$ and Zanetti et al. ${ }^{12}$. The documents of the CFE and CFO were selected, because they were the main normative instruments within the scope of the educational system and professional exercise prior to the law.

The questionnaire was organized in two blocks with the following categories: block I - Identification and Education: year of entry into public service, and year of graduation from the university; health center at which the professional worked, aspects related to post-graduation; Block II - Work Process: 36 clinical, administrative and health care actions that had to be marked according to the CDs' work process: whether they would delegate to the ASB and/or TSB, of would delegate only to the TSB, or would not delegate.

Within the listof action, some that were deleted from the legislation; and some that were listed in the CFE or CFO document, were listed. These were: "Be responsible for administration of the clinic"; "Educate and guide patients (or groups) about treatment of oral health diseases"; "Perform the pulp vitality test"; "Prepare trays" and "Polish restorations" and others that did not form part of the attributions that had already been formally expressed, such as "clean the dental office including washing and drying the floor, cleaning walls, etc.". The purpose of this insertion refers to the fact that the proposal of the study was to evaluate the adequacy of delegating the activities, in accordance with the rule in force.

The questionnaires were delivered to all of the 180 dentists by means of partnership with the center of education of health workers ("Centro de Educação dos Trabalhadores em Saúde - (ETS") that distributed the questionnaires as from October 2014 and collected them by means of mail bags. One researcher was in direct contact with the dentists in case of non-return, in subsequent attempts to increase the response rate, carried out until July 2015 . The response rate obtained was $36 \%$, and 64 dentists participated.

\section{Data analysis}

The data were tabulated and analyzed afterwards by means of the table of distribution of absolute and relative frequencies, considering adequacy to the legislation in force. The actions in which the absolute majority of respondents marked the correct option about the delegation of actions to the auxiliary team were consider in conformity with the legislation. For data classification, the analysis performed by Frazão \& Narvai ${ }^{13}$ was considered, taking as reference the skills in terms of direct actions - those when the patient was provided with the action, and indirect actions, those corresponding to the activities the dentist was provided with at the chairside, and or support with assistance. The actions were also classified according to four skills: 'Health promotion and prevention of diseases'; 'Prevention and control of oral diseases'; 'Organization of the work environment' and 'Clinical oral health care'14.

\section{RESULTS}

The mean time since graduation was $22.1( \pm 7.4)$ years and time of work in the public system was $16.2( \pm 8.9)$ years. Of the participants, $73.4 \%(n=47)$ reported having done Postgraduate courses, and 35 professionals were specialized in courses in the Collective Health area.

In Table 1, according to the four skills analyzed, it may be observed that for the absolute majority of the respondents, the tasks that were delegated in accordance with the law fitted into the following skills: "Clinical care in oral health" and "Organization of the work environment" while those related to the skill "Health Promotion and Prevention of Diseases" were the skills that presented proportionally greater divergence in relation to the law.

Table 2 presents the results of the present study, considering the actions in the work process in which the majority $(\geq 50 \%)$ of the respondents reported delegating, which were in accordance with the provision in Law $11,889 / 2008$. Please note that $61.1 \%$ (22) of the actions explained in the instrument were adequately delegated; among which, 11 had an adequate response from over $90 \%$ of the respondents. A fact that drew attention referred to the classification of these actions: the majority were indirect actions both among the 22 listed (64\%) and among those with higher frequency of correct responses (82\%). The authors point out that among the 20 actions that are foreseen in the Law, 85\% (20) were attributions of the assistants, and consequently of the technicians; only $15 \%$ (3) of the correctly delegated actions were attributions exclusively of the TSB.

Table 3 presents the actions of the work process of dental surgeons, for whom the majority of the responses were in disagreement with the attributions described in Law 11.889/2008. Considering the 14 actions described (6 indirect and 8 direct), 4 of them were no listed in the 
legislation and were marked as being delegated to the assistants, characterizing extrapolation of functions. Among the attributions exclusively of the TSB $(64.3 \%, 9), 44.4 \%$ (4) were marked by the majority of dentists as "I do not delegate/would not delegate", characterizing under-use of the technician, while $55.6 \%$ (5) of them were delegated to the assistant, characterizing extrapolation of the function of the ASB.

Table 1. Distribution of the skills of actions evaluated, considering compliance with Law 11889. Campinas (SP), 2015.

\begin{tabular}{|c|c|c|c|c|c|c|c|c|c|c|c|c|c|c|}
\hline \multirow{3}{*}{ Competences } & \multicolumn{6}{|c|}{ Compliance with the law } & \multicolumn{6}{|c|}{ Disagreement with the law } & \multicolumn{2}{|c|}{ General total } \\
\hline & \multicolumn{2}{|c|}{ Direct action } & \multicolumn{2}{|c|}{ Indirect Action } & \multicolumn{2}{|c|}{ Total } & \multicolumn{2}{|c|}{ Direct action } & \multicolumn{2}{|c|}{ Indirect Action } & \multicolumn{2}{|c|}{ Total } & \multirow[b]{2}{*}{$\mathrm{n}$} & \multirow[b]{2}{*}{$\% \$$} \\
\hline & $\mathrm{n}$ & $\% *$ & $\mathrm{n}$ & $\%$ * & $\mathrm{n}$ & $\% \$$ & $\mathrm{n}$ & $\%$ * & $\mathrm{n}$ & $\%$ * & $\mathrm{n}$ & $\%$ & & \\
\hline $\begin{array}{l}\text { Clinical } \\
\text { attendance in } \\
\text { oral health }\end{array}$ & 4 & 50.0 & 4 & 50.0 & 8 & 57.1 & 5 & 35.7 & 1 & 7.1 & 6 & 42.9 & 14 & 38.9 \\
\hline $\begin{array}{l}\text { Organization } \\
\text { of the Work } \\
\text { Environment }\end{array}$ & 2 & 18.2 & 9 & 81.8 & 11 & 78.6 & 0 & 0.0 & 3 & 21.4 & 3 & 21.4 & 14 & 38.9 \\
\hline $\begin{array}{l}\text { Prevention } \\
\text { and Control } \\
\text { of Oral } \\
\text { Diseases }\end{array}$ & 2 & 100.0 & 0 & 0.0 & 2 & 50.0 & 2 & 50.0 & 0 & 0.0 & 2 & 50.0 & 4 & 11.1 \\
\hline $\begin{array}{l}\text { Health } \\
\text { Promotion } \\
\text { and } \\
\text { Prevention of } \\
\text { Diseases }\end{array}$ & 0 & 0.0 & 1 & 100.0 & 1 & 25.0 & 1 & 25.0 & 2 & 50.0 & 3 & 75.0 & 4 & 11.1 \\
\hline General total & 8 & 36.4 & 14 & 63.6 & 22 & 61.1 & 8 & 22.2 & 6 & 16.7 & 14 & 38.9 & 36 & 100 \\
\hline
\end{tabular}

Note: * Relative Frequency in relation to partial total, in each group. \$Relative Frequency in relation to general total.

Table 2. Routine work actions of dental surgeons, whose delegation was correct for over half of the respondents. Campinas. September 2015.

\section{Routine work actions}

\section{Clinical attendance in oral health}

Manipulate materials for dental use.

Assist and provide the dentist with instruments in clinical environments;

Provide the professional with instruments at the operative chair-side.

Perform pulp vitality tests,

Perform supra gingival calculus removal, according to

the technique defined by the CD.

Perform biofilm removal, according to the technique defined by the CD.

Process radiographic film.

Polish restorations.

\section{Organization of the Work Environment}

Prepare the patient for attendance
Perform cleaning, asepsis, disinfection and sterilization

of the work environment.

Conserve and maintain equipment

Perform cleaning, disinfection and sterilization of the

dental instruments.

Keep the files and record charts in order

Apply biosafety measure in storage, transport,

handling and discarding products and dental residues.

Receive the patient at the oral health services.

Schedule appointments for consultations.

Adopt biosafety measures, with the purpose of controlling infection.

Fill out clinical record charts.

Record and participate in analysis of information

related to administrative control in oral health.

Prevention and Control of Oral Diseases

Organize and perform oral hygiene activities.

Perform topical fluoride application as directed by the

dental surgeon (CD)

Type of action

Indirect

Indirect

Indirect

Direct

Direct

Direct

Indirect

Direct

Direct

Indirect

Indirect

Indirect

Indirect

Indirect

Direct

Indirect

Indirect

Indirect

Indirect

irect

Direct

Direct

Indirect
Attributes

In accordance with Law $11889 / 2008$

$96.90 \%$

$93.80 \%$

$93.80 \%$

$79.70 \%$

$76.60 \%$

$68.80 \%$

$51.60 \%$

$51.60 \%$

$\begin{array}{ll}\text { ASB and TSB } & 51.60 \% \\ \text { Not stated } & 51.60 \%\end{array}$

ASB and TSB 95.30\%

ASB and TSB $\quad 95.30 \%$

ASB and TSB $\quad 95.30 \%$

ASB and TSB $\quad 93.80 \%$

ASB and TSB $\quad 93.80 \%$

ASB and TSB $\quad 92.20 \%$

ASB and TSB $\quad 90.60 \%$

ASB and TSB $\quad 90.60 \%$

ASB and TSB $\quad 85.90 \%$

ASB and TSB $\quad 62.50 \%$

ASB and TSB $\quad 51.60 \%$ 
Table 3. Work process actions of the dental surgeons, whose delegation differed from the attributions described in the legislation for over half of the responses. Campinas September 2015.

\begin{tabular}{|c|c|c|c|c|}
\hline Routine work actions & $\begin{array}{l}\text { Type of } \\
\text { action }\end{array}$ & Attributes & Classification & $\begin{array}{c}\text { In accordance with Law } \\
11889 / 2008 \\
\end{array}$ \\
\hline Prepare plaster models & Indirect & ASB and TSB & Under-uses TSB and ASB & $43.80 \%$ \\
\hline Take photographs and radiographs & Direct & TSB & Under-uses TSB & $37.50 \%$ \\
\hline $\begin{array}{l}\text { During cavity preparation, distribute dental } \\
\text { materials in direct dental restoration. }\end{array}$ & Direct & TSB & Under-uses TSB & $34.40 \%$ \\
\hline Perform isolation of the operating field & Direct & TSB & Under-uses TSB & $26.60 \%$ \\
\hline \multicolumn{5}{|l|}{ Organization of the Work Environment } \\
\hline $\begin{array}{l}\text { Cleaning the dental office (washing and drying } \\
\text { the floor, cleaning the walls, etc.). }\end{array}$ & Indirect & Not stated & Extrapolates assistants & $43.80 \%$ \\
\hline Answerable for administration of the clinic. & Indirect & Not stated & Extrapolates assistants & $40.60 \%$ \\
\hline Teach Oral Hygiene Technicians & Direct & TSB & Extrapolates ASB & $6.30 \%$ \\
\hline \multicolumn{5}{|l|}{$\begin{array}{l}\text { Health Promotion and Prevention of } \\
\text { Diseases }\end{array}$} \\
\hline $\begin{array}{l}\text { Train and qualify community agents for oral } \\
\text { health promotion actions. }\end{array}$ & Indirect & TSB & Extrapolates ASB & $14.10 \%$ \\
\hline $\begin{array}{l}\text { Participate in educational actions (health } \\
\text { promotion and oral disease prevention) }\end{array}$ & Direct & TSB & Extrapolates ASB & $6.30 \%$ \\
\hline $\begin{array}{l}\text { Participate in epidemiological surveys in the } \\
\text { function of note taker or monitor }\end{array}$ & Indirect & TSB & Extrapolates ASB & $6.30 \%$ \\
\hline
\end{tabular}

The authors, however, emphasize that the frequency of responses in agreement with the law was not higher than $50 \%$ for the attributions "Prepare plaster models" and "Remove sutures", as the responses were distributed among the following options of the instrument: (I delegate/would delegate to ASB and TSB; delegate/ would delegate only to TSB, I do not delegate/would not delegate), although the option with the highest number of responses was adequate to the legislation. Although the action "Prepare plaster models" was an attribution of both professional assistants, $17.2 \%$ of the dentists delegated it only to the TSB, while $29.7 \%$ of them did not delegate/ would not delegate this action. Relative to the action of removal of sutures, exclusive attribution of TSB, $23.4 \%$ of the respondents delegated it to the ASBs and $37.5 \%$ did not delegate it to the auxiliary personnel.

\section{DISCUSSION}

To enable the oral health team to work in an integrated manner, respectfully, and attain their maximum productivity, not only is incorporation of the auxiliary personnel required, but the dentist needs to know how to delegate functions ${ }^{9-10}$, thereby allowing the role played by assistants and technicians to attain its potentialities, and allowing the development of their professional skills and attributions that culminate in extending the profile of dental practice ${ }^{14}$. In the public sector, it is extremely important to organize the work and delegate in the correct manner, so that among other gains, a larger number of persons could be contemplated to receive oral health care actions $5,7,18$. However, in a recent analysis, Warmling et al. ${ }^{14}$ discussed Law 11.889/2008 indicating that it has not been shown to be a legal instrument capable of encouraging promotion of extending the skills and attributions of these workers.

The rate of return of the questionnaires in the present study, $36 \%$ of the sample universe, was higher than the return of $25 \%$ expected for studies involving this methodology ${ }^{19-20}$. These rates ranged from $19.1 \%{ }^{21}$ to $25.4 \% 15$ and was considered satisfactory, also considering the Brazilian culture of infrequent 
participation in researches 22 .

In the present study, the authors noted that the majority of the actions proposed were being delegated in compliance with the legislation. Generally speaking, the functions most correctly delegated were those of indirect action; these are common to assistants and technicians. The actions that were exclusively the functions of the TSB were those that presented the most inconsistency in relation to the legislation. This finding corroborates the data that have been pointed out in the literature: that there are no significant differences between the work process performed by the oral health assistants and technicians, since the skills and attributions marked by the assistants were also reported by the technicians, resulting in a low number of attributions that were exclusively of the latter ${ }^{14}$.

Studies conducted before the regulation of the professions ${ }^{11,23-24}$ verified that the majority of the auxiliary personnel mainly perform the functions of reception, preparation of the patient, developing radiographs, while the functions of an educationalpreventive nature are shown with lower frequency. In the present study, the actions related to organization of the work environment were those most correctly delegated, while those of clinical care in oral health were those most cut off from the technicians. Warmling et al. ${ }^{14}$ verified that the auxiliary professionals that were active in SUS worked more intensely with the skills of health promotion and prevention of disease, which has a relationship with the findings of this study, however, the extrapolation of ASB functions was noted. Furthermore, important regional differences should be considered; the TSB have hardly been absorbed into dental services, a reality also found in the municipality of Campinas. When this occurs, it has been noted that this is limited both to performing the role destined to the $\mathrm{ASB}^{14}$ and to $\mathrm{ASB}$ performing actions exclusively those of the technician, as may be noted in the present study.

Some functions were delegated to the ASB that were attributed specifically to the TSB, such as the training and qualification of community agents for oral health promotion actions; cleaning and antisepsis of the operating fields before and after surgical procedures; participation in educational actions for health promotion and prevention of oral diseases; participation in epidemiological surveys, and teaching oral hygiene techniques. In these situations, the authors noted that the extrapolations verified were relative to reversible actions that could be redone without damage to the work or user ${ }^{24}$.

At this point, it is worth pondering the practical difference between the attributions exclusively of the TSB: "teach oral hygiene techniques and perform prevention of oral diseases by means of topical fluoride application, according to the dental surgeons instructions" and the attribution "organize and perform oral hygiene activities" of the ASB skill. Although the instrument was elaborated based on the text of the legislation, in practice in the municipality, supervised tooth brushing performed at the schools is carried out by the ASB and the similarity in the attributions may be the reason for the response in disagreement with the law. This may be justified by the nature of professionals' autonomy foreseen by the Ministry of Health², which guarantees that the professional transcends the prescriptions, but this is not synonymous with independence, rather with interdependence, characterizing commitment and interaction between the parties.

Actions that should be delegated to the TSB and that denoted their under-use in the public service of Campinas, such as "Remove sutures", "During cavity preparation, distribute dental materials in direct dental restorations" ad "Perform isolation of the operating field" suggested situations pointed out in the literature with regard to the role of the TSB in health actions: misinformation about the work process and presence of concerns about the legal responsibility of CDs about activities developed by $\mathrm{TSBs}^{5}$, which lead to the need for complementary studies that qualitatively investigate the reasons why professionals reported that they did not delegate these activities. Relative to the actions "Prepare plaster models" and "take photographs and radiographs" the result was predictable, considering that the actions performed in primary care do not involve impression taking, and the absence of $x$-ray appliances in the Health Centers.

Organization of the work in oral health must contemplate the participation of the TSBs, so that they also perform clinical attendance in individual actions, therefore, there is need of adequate physical space for their work ${ }^{5}$. This is guaranteed to Modality 2 oral health teams, by means of incentives to acquire an additional dental office, in accordance with Administrative Ruling 
GM/MS No. 2,372, of October 7, 200925. In the present study there was no visit to the CS, and therefore, the adequacy of the work space was not evaluated.

\section{CONCLUSION}

The majority of the oral health teams' (ESB) actions are being delegated in a manner compatible with the legal provision, however, there are situations of extrapolation of functions, especially to assistants, and under-use of professionals, especially of the oral health technicians.

\section{ACKNOWLEDGMENTS}

The authors thank the São Paulo State Research Support Foundation - FAPESP for granting a scientific initiation study bursary (2014/11194-3) to the center of

\section{REFERENCES}

1. Sá EMO, Melo MB, Cavalcanti CAT, Oliveira LA, Pereira NNR, Marques ORA, et al. The attributions of the oral health technician: practice systematization. Trab Educ Saúde. 2010;8(3):463-484. doi: 10.1590/S1981-77462010000300008

2. Brasil. Ministério da Saúde. Perfil de competências profissionais do técnico em higiene dental e do auxiliar de consultório dentário. Brasília: Ministério da Saúde; 2004.

3. Brasil. Ministério da Saúde. Secretaria de Atenção à Saúde. Departamento de Atenção Básica. Coordenação Nacional de Saúde Bucal. Diretrizes da política nacional de saúde bucal. Brasília: Ministério da Saúde, 2004 [citado 2016 Nov 10]. Disponível em: < http://189.28.128.100/dab/docs/publicacoes/ geral/diretrizes_da_politica_nacional_de_saude_bucal.pdf $>$.

4. Brasil. Lei Federal $n^{\circ} 11.889$, de 24 de dezembro de 2008 . Regulamenta o exercício das profissões de Técnico e Saúde Bucal (TSB) e de Auxiliar em Saúde Bucal (ASB). Brasília: Ministério da Saúde; 2008.

5. Espositi CD, Oliveira AE, Neto ETS, Zandonade E. O processo de trabalho do técnico em saúde bucal e suas relações com a equipe de saúde bucal na Região Metropolitana da Grande Vitória, Espírito Santo, Brasil. Saúde Soc. 2012;21(2):372-85. doi: 10.1590/S0104-12902012000200011

6. Brasil. Ministério da Saúde. Departamento de Atenção Básica. Evolução do credenciamento e implantação da Estratégia Saúde da Família. Brasília: Ministério da Saúde. [s.d.]. [citado 2016 Nov 10]. Disponível em: <http://dab.saude.gov.br/cnsb/historico cobertura_sf.php>.

7. Pezzato LM, Cocco MIM. O técnico em higiene dental e o atendente de consultório dentário no mundo do trabalho. Saúde Debate. 2004;28(68):212-19. workers in the field of health (" Centro de Educação dos Trabalhadores da Saúde - CETS), through its coordinator Alóide Ladeia Guimarães and to the Oral Health Area of the Municipal Secretary of Health, through intermediary of Dr. Isamu Murakami, and making it possible to develop the study, and also thank the volunteers for their inestimable cooperation.

\section{Collaborators}

MB LOURENÇO cooperated with the bibliographical research, data collection, preliminary and final composing. AMG OLIVEIRA and L ZANIN cooperated in the article's conception and data analysis. FM FLÓRIO guided the study conception and the data analysis. Cooperated in preliminary review and correction on the final composing.

8. Silva RF, Monini AC, Neto JV, Júnior LF, Júnior ED. Percepção dos auxiliares odontológicos na clínica ortodôntica quanto aos seus limites de atuação profissional. Rev Dent Press Ortodon Ortop Facial. 2009;14(3):34-9. doi: 10.1590/S141554192009000300005

9. Freire ACGF, Garbin AJI, Rovida TAS, Garbin CAS. O conhecimento das funções e a formação dos auxiliares odontológicos atuantes no serviço público de saúde de municípios do noroeste paulista. Rev Bras Pesq Saúde. 2011;13: 5-9

10. Queluz DP. Perfil dos profissionais auxiliares da odontologia e suas implicações no mercado de trabalho. Rev Odonto Ciência. 2005;20:270-80

11. Saliba TA, Euletério D, Saliba CA, Moimaz SAS. Trabalho odontológico auxiliado em serviços públicos e particulares. RPG Rev Pos-grad. 1998;5:171-6.

12. Zanetti CHG, Oliveira JAA, Mendonça MHM. Divisão do trabalho odontológico em perspectiva: desafio de interpretar as competências dos técnicos. Trab Educ Saúde. 2012;10(2):195222. doi: 10.1590/S1981-77462012000200002

13. Frazão P, Narvai PC. Lei n. 11.889/2008: avanço ou retrocesso nas competências do técnico em saúde bucal? Trab Educ Saúde. 2011:9:109-23.

14. Warmiling CM, Rosa EK, Pezzato LM, Toassi RFC. Competências de auxiliares e técnicos de saúde bucal e o vínculo com o Sistema Único de Saúde. Trab Educ Saúde. 2016;14(2):575-92. doi: 10.1590/1981-7746-sip00116

15. Paranhos LR, Tomasso S, Ricci ID, Siqueira DF, Scanavini MA Atribuições e implicações legais dos profissionais auxiliares da odontologia: visão do próprio auxiliar. RGO, Rev Gauch Odontol. 2009;57:77-85.

16. Conselho Federal de Educação. Parecer n. 460, de 6/2/1975. Dispõe sobre a habilitação de Técnico em Higiene Dental e 
Atendente de Consultório Dentário. Diário Oficial da República Federativa do Brasil, Poder Executivo, Brasília, DF, 07/04/1975. Seção I, p. 3.937.

17. Conselho Federal de Odontologia. Resolução n. 63, de 18/4/2005. Aprova a consolidação das normas para procedimentos em conselhos de odontologia. Diário Oficial da República Federativa do Brasil, Poder Executivo, Brasília, DF, Seção 1, 19/04/2005 p. 104.

18. Lazeris AM, Calvo MCM, Regis Filho GIA. A formação de recursos humanos em odontologia e as exigências do setor público: uma contribuição para serviços de saúde públicos e de qualidade. Rev Odonto Ciênc. 2007;22:166-76.

19. Oliveira MA, Fulgêncio VS, Durães AEA, Damião BM, Oliveira CMCS, Carvalho CM, et al. Auxiliar e técnico de saúde bucal: da condição de 'ocupação' ao status de 'profissão' da odontologia. Trab Educ Saúde. 2014;12(1):69-85.

20. Marconi, MA, Lakatos EM. Técnicas de pesquisa: planejamento e execução de pesquisas, amostragens e técnicas de pesquisa, elaboração, análise e interpretação de dados. 4a ed. Atlas: São Paulo: 1999.

21. Costa, AO, Silva LP, Saliba O, Garbin AJI, Moimaz SAS. A participação do auxiliar em saúde bucal na equipe de saúde e o ambiente odontológico. Rev Odontol UNESP. 2012;41:371-6. doi: 10.1590/S1807-25772012000600001

22. Saliba NA, Moimaz SAS, Prado RLD, Garbin CAS. Percepção do cirurgião-dentista sobre formação profissional e dificuldades de inserção no mercado de trabalho. Rev Odontol UNESP. 2012;41(5):297-304. doi: 10.1590/s1807-25772012000500001

23. Serra MC, Garcia PPNS. Delegação de funções: utilização de pessoal auxiliar na clínica odontológica. Rev ABO Nac. 2002; 10:98-104. doi.org/10.1590/S1415-54192009000300005.

24. Sales CVM, Pinto AEA, Cavalcanti AL, Lucas RSCC, Lins SA. Delegação de funções ao pessoal auxiliar odontológico pelos cirurgiões-dentistas da cidade de Campina Grande-PB. Rev Ciências Méd Biol. 2007;6(1):47-53. doi: 10.9771/cmbio. v6i1.4148

25. Brasil. Portaria GM/MS n 2.372, de 7 de outubro de 2009. Cria o plano de fornecimento de equipamentos odontológicos para as Equipes de Saúde Bucal na Estratégia Saúde da Família. Brasília: Ministério da Saúde; 2009 [citado 2016 Nov 13]. Disponível em: $<$ http://dab.saude.gov.br/portaldab/plano_fornecimento_esb. php $>$.
Received on: 29/4/2017

Final version resubmitted on: 5/7/2017

Approved on: 31/7/2017 